\title{
Szórványleletek a Magyar Természettudományi Múzeum gyủjteményében: Óriásszalamandra, †Andrias scheuchzeri (Holl, 1831) farokcsigolyák a késő-miocén pannon pécs-danitzpusztai (Magyarország) ösgerinces lelőhelyről (Caudata: Amphibia: Cryptobranchidae)
}

\author{
SZENTESI Zoltán \\ Magyar Természettudományi Múzeum, Öslénytani és Földtani Tár, \\ 1083 Budapest, Ludovika tér 2-6., Magyarország \\ E-mail: szentesi.zoltan@nhmus.hu
}

\begin{abstract}
Összefoglalás - Magyarországról egyedül a pécs-danitzpusztai késő-miocén korú ösgerinces lelőhelyről ismerünk óriásszalamandra, $†$ Andrias scheuchzeri (Holl, 1831) fosszíliákat, melyek craniális és postcraniális csontokat egyaránt tartalmaznak. Ennek ellenére, a fajhoz sorolható farokcsigolyák még nem kerültek leírásra innen. Ezt a hiányosságot igyekszik bepótolni jelen munka néhány paleoökológiai és ősföldrajzi megjegyzéssel kiegészítve. Kilenc ábra, egy táblázat.
\end{abstract}

Kulcsszavak - Andrias, Cryptobranchidae, Danitzpuszta, Mecsek, miocén, vertebra

\section{BEVEZETÉS}

A Cryptobranchidae családba olyan nagytestű szalamandrák tartoznak, melyek testhossza meghaladja az 1,5 métert, míg egyes fajoknál a 2 métert is elérheti. Az ide sorolható fosszilis leletek jelenléte Ázsiában azt sugallja, hogy a család története a középső-juráig nyúlik vissza (GAO \& SHUBIN 2003). ÉszakAmerikában a paleocéntől (NAYLOR 1981) máig élnek óriás szalamandrák (BROWNE et al. 2012), míg Kelet-Ázsiában fosszíliáik gyakoriak a késő-eocéntől (CHERnov 1959), de recens képviselöik mindmáig jelen vannak (BROWNe et al. 2012). Európában a középső oligocéntől a középső-pliocénig ismertek fosszilis maradványaik (Thenius 1954, WestPHAL 1958, 1967, 1970, TATARINOV 1964, ČHI KVADZE 1981). Az órásszalamandra leletek az eurázsiai ősmaradvány rekordban különösen jól reprezentáltak (1. táblázat), maradványaik számos ősgerinces lelőhelyről kerültek elő részlegesen megőrződött csontvázként vagy izolált csontokként (BöHME \& Ilg 2003, VASILYAN $e t$ al. 2013, Szentesi $e t$ al. 2020). Magyarországról eddig bizonyítottan csak a pécs-danitzpusztai lelőhelyről ismerjük izolált csontmaradványait (SzENTESI et al. 2020). 
A pécs-danitzpusztai homokbánya a középső-miocéntől (badeni-szarmata) a késő-miocénig (pannon) terjedő rétegeket tár fel (SEBE et al. 2015). A bányászott homok, mely egy klasszikus pannóniai feltárás, a molluszka-maradványokon kívül kiemelkedő jelentőségủ gerinces faunát tárt fel, melyek jelentős része idősebb üledékekből halmozódott át. Nagy mennyiségben fordulnak elő porcosés csontos halak fogai, teknőspáncél-töredékek, szilás- és fogascetek csigolyái. Gyakorinak mondhatóak a különféle szárazföldi gerincesek maradványai is, mint pl. tapír-, disznó- és antilopfélék, valamint ragadozókhoz sorolható csontleletek is előfordulnak az innen származó leletanyagban (KAZÁR et al.2007, KONRÁD et al. 2010). Az óriásszalamandra leletek, melyek közül eddig négy maxilla, 16 dentale, négy atlas és három törzscsigolya, valamint egy ilium és egy femur vált eddig ismertté, a késő-miocén korú homokból kerültek elő. Jelen munkában két caudális vertebra kerül leírásra.

1. táblázat. Óriásszalamandra ( $†$ Andrias, Cryptobranchidae) ősgerinces lelőhelyek Európában.

\begin{tabular}{|c|c|c|c|c|c|}
\hline Lelőhely/locality & kor/age & $\begin{array}{l}\text { zóna/ } \\
\text { zone }\end{array}$ & $\begin{array}{l}\text { üledék típusa/ } \\
\text { alluvial type }\end{array}$ & foszíliák/fossils & említve/reference \\
\hline Rott, Németország & $\begin{array}{l}\text { középső- } \\
\text { oligocén }\end{array}$ & MP30 & édesvízi molasz & osseus partem & $\begin{array}{l}\text { TheniUs } 1954, \\
\text { WestPhal } \\
\text { 1958, 1967, 1970, } \\
\text { Meszoely } 1966 \text {, } \\
\text { BöHME } 2003\end{array}$ \\
\hline $\begin{array}{l}\text { Oberleitersbach, } \\
\text { Németország }\end{array}$ & $\begin{array}{l}\text { felső- } \\
\text { oligocén }\end{array}$ & katti & $\begin{array}{l}\text { karsztos } \\
\text { üregkitöltés i }\end{array}$ & $\begin{array}{l}\text { mandibula, } \\
\text { maxilla, dentale }\end{array}$ & ВӧнмЕ 2008 \\
\hline Merkur, Csehország & alsó-miocén & MN3a & meszes márga & ossa isolata & $\begin{array}{l}\text { BÖHME } 2003, \\
\text { ČER ̌̌ANSKỲ } 2007, \\
\text { KVAČEK et al. } 2004\end{array}$ \\
\hline $\begin{array}{l}\text { Břeštany, Csehország, } \\
\text { (=Preschen im } \\
\text { Böhmen vagy Bilina) }\end{array}$ & alsó-miocén & MN3 & $\begin{array}{l}\text { fluviális } \\
\text { üledékek i }\end{array}$ & $\begin{array}{l}\text { vertebrae } \\
\text { articulata, cranium, } \\
\text { osseus partem }\end{array}$ & $\begin{array}{l}\text { WESTPHAL, } 1958 \text {, } \\
\text { MESZOELY } 1966, \\
\text { KVAČEK et al. } 2004 \text {, }\end{array}$ \\
\hline $\begin{array}{l}\text { Hochberg, } \\
\text { Németország }\end{array}$ & alsó-miocén & $\mathrm{MN} 3$ & molasz & mandibula & WESTPHAL 1970 \\
\hline $\begin{array}{l}\text { Illerkirchberg hor. } \\
\text { 3a, Németország }\end{array}$ & alsó-miocén & MN3 & molasz & dentale, maxilla & $\begin{array}{l}\text { BÖTTCHER } \\
\text { 1987, SACH \& } \\
\text { HEINZMANN } 2001\end{array}$ \\
\hline $\begin{array}{l}\text { Ringingen Frontal 1, } \\
\text { Németország }\end{array}$ & alsó-miocén & MN3 & $\begin{array}{l}\text { homokos finom } \\
\text { kavics }\end{array}$ & $?$ & $\begin{array}{l}\text { SACH \& } \\
\text { HEINZMANN } 2001\end{array}$ \\
\hline
\end{tabular}




\begin{tabular}{|c|c|c|c|c|c|}
\hline Lelöhely/locality & kor/age & $\begin{array}{c}\text { zóna/ } \\
\text { zone }\end{array}$ & $\begin{array}{l}\text { üledék típusa/ } \\
\text { alluvial type }\end{array}$ & foszíliák/fossils & említve/reference \\
\hline Ringingen Frontal 2 & alsó-miocén & MN3 & agyagmárga & $?$ & $\begin{array}{l}\text { SACH \& } \\
\text { HEINZMANN } 2001\end{array}$ \\
\hline $\begin{array}{l}\text { Eggingen, } \\
\text { Németország }\end{array}$ & alsó-miocén & MN4 & brakkvízi molasz & maxilla, vertebra & $\begin{array}{l}\text { BÖTTCHER } \\
\text { 1987, SACH \& } \\
\text { HEINZMANN } 2001\end{array}$ \\
\hline $\begin{array}{l}\text { Illerkirchberg, } \\
\text { Németország }\end{array}$ & alsó-miocén & MN4 & $\begin{array}{l}\text { homok, } \\
\text { mészhomok }\end{array}$ & ? & $\begin{array}{l}\text { SACH \& } \\
\text { HEINZMANN } 2001\end{array}$ \\
\hline $\begin{array}{l}\text { Jungnau, } \\
\text { Németország }\end{array}$ & alsó-miocén & MN4 & brakkvízi molasz & $?$ & BötTCHER 1987 \\
\hline $\begin{array}{l}\text { Langenau, } \\
\text { Németország }\end{array}$ & alsó-miocén & MN4 & brakkvízi molasz & dentale, vertebra & BötTCHER 1987 \\
\hline $\begin{array}{l}\text { Oberkirchberg, } \\
\text { Németország }\end{array}$ & alsó-miocén & MN4 & brakkvízi molasz & vertebra & BötTCHER 1987 \\
\hline $\begin{array}{l}\text { Hambach, } \\
\text { Németország }\end{array}$ & alsó-miocén & MN5 & $\begin{array}{l}\text { fluviális } \\
\text { üledékek }\end{array}$ & vertebra & $\begin{array}{l}\text { MöRs et al. } 2000 \text {, } \\
\text { BöHмE } 2003\end{array}$ \\
\hline $\begin{array}{l}\text { Reisensburg, } \\
\text { Németország }\end{array}$ & $\begin{array}{l}\text { középső- } \\
\text { miocén }\end{array}$ & MN6 & molasz & $\begin{array}{l}\text { dentale, maxilla, } \\
\text { vertebra }\end{array}$ & $\begin{array}{l}\text { Meszoely 1966, } \\
\text { Böttcher } 1987\end{array}$ \\
\hline $\begin{array}{l}\text { Öhningen, } \\
\text { Németország }\end{array}$ & $\begin{array}{l}\text { középső- } \\
\text { miocén }\end{array}$ & $\mathrm{MN6/7}$ & édesvízi molasz & osseus partem & Meszoely 1966 \\
\hline $\begin{array}{l}\text { Kircheim, } \\
\text { Németország }\end{array}$ & $\begin{array}{l}\text { középső- } \\
\text { miocén }\end{array}$ & MN7 & molasz & $\begin{array}{l}\text { maxilla, premaxilla, } \\
\text { vertebra }\end{array}$ & , BöтtсHER 1987 \\
\hline Mataschen, Ausztria & $\begin{array}{l}\text { felső- } \\
\text { miocén }\end{array}$ & $\mathrm{MN} 7 / 8$ & agyag, homok & maxilla, vertebra & $\begin{array}{l}\text { Thenius } 1954, \\
\text { Meszoely } 1966, \\
\text { Tempfer } 2004\end{array}$ \\
\hline $\begin{array}{l}\text { Wartenberg, } \\
\text { Németország }\end{array}$ & $\begin{array}{l}\text { felső- } \\
\text { miocén }\end{array}$ & MN8 & molasz & $\begin{array}{l}\text { maxilla, premaxilla, } \\
\text { vertebra }\end{array}$ & $\begin{array}{l}\text { Meszoely } 1966 \text {, } \\
\text { WestPhAL } 1970 \text {, } \\
\text { BÖTtCHeR } 1987\end{array}$ \\
\hline Götzendorf, Ausztria & $\begin{array}{l}\text { felső- } \\
\text { miocén }\end{array}$ & MN8 & agyag & $\begin{array}{l}\text { keratobranchiale, } \\
\text { maxilla, atlas, } \\
\text { costas, vertebra }\end{array}$ & $\begin{array}{l}\text { Meszoely } 1966, \\
\text { Miklas } 2002\end{array}$ \\
\hline
\end{tabular}




\begin{tabular}{|c|c|c|c|c|c|}
\hline Lelöhely/locality & kor/age & $\begin{array}{l}\text { zóna/ } \\
\text { zone }\end{array}$ & $\begin{array}{l}\text { üledék típusa/ } \\
\text { alluvial type }\end{array}$ & foszíliák/fossils & említve/reference \\
\hline Aspach, Németország & $\begin{array}{l}\text { felső- } \\
\text { miocén }\end{array}$ & MN9 & homok, márga & $?$ & SeEhuber 2008 \\
\hline $\begin{array}{l}\text { Derndorf, } \\
\text { Németország }\end{array}$ & $\begin{array}{l}\text { felső- } \\
\text { miocén }\end{array}$ & MN9 & homok & dentale & $\begin{array}{l}\text { BöHME 2003, } \\
\text { SEEHUBER } 2008\end{array}$ \\
\hline $\begin{array}{l}\text { Eppishausen, } \\
\text { Németország }\end{array}$ & $\begin{array}{l}\text { felső- } \\
\text { miocén }\end{array}$ & MN9 & homok & $?$ & $\begin{array}{l}\text { BÖHME } 2003, \\
\text { SEEHUBER } 2008\end{array}$ \\
\hline $\begin{array}{l}\text { Mörgen, } \\
\text { Németország }\end{array}$ & $\begin{array}{l}\text { felső- } \\
\text { miocén }\end{array}$ & MN9 & homok & dentale & ВÖH ME 2003 \\
\hline $\begin{array}{l}\text { Tiefenried, } \\
\text { Németország }\end{array}$ & $\begin{array}{l}\text { felső- } \\
\text { miocén }\end{array}$ & MN9 & homok & $?$ & $\begin{array}{l}\text { SEEHUBER } 2008, \\
\text { BÖHME } \text { et al. } 2012\end{array}$ \\
\hline $\begin{array}{l}\text { Brunn-Vösendorf, } \\
\text { Ausztria }\end{array}$ & $\begin{array}{l}\text { felső- } \\
\text { miocén }\end{array}$ & MN9 & congériás homok & humerus, vertebra & $\begin{array}{l}\text { TheniUs } 1954, \\
\text { Meszoely } 1966 \text {, } \\
\text { BötTCHER } 1987\end{array}$ \\
\hline $\begin{array}{l}\text { Hammerschmiede } 1 \text {, } \\
\text { Németország }\end{array}$ & $\begin{array}{l}\text { felső- } \\
\text { miocén }\end{array}$ & MN9 & agyag & $?$ & BöHмE et al. 2012 \\
\hline $\begin{array}{l}\text { Hammerschmiede } 4 \text {, } \\
\text { Németország }\end{array}$ & $\begin{array}{l}\text { felső- } \\
\text { miocén }\end{array}$ & MN9 & agyag & ? & $\begin{array}{l}\text { KIRSCHER et al. } \\
2016\end{array}$ \\
\hline $\begin{array}{l}\text { Hammerschmiede } 5 \text {, } \\
\text { Németország }\end{array}$ & $\begin{array}{l}\text { felső- } \\
\text { miocén }\end{array}$ & MN9 & agyag & ? & $\begin{array}{l}\text { KIRSCHER et al. } \\
2016\end{array}$ \\
\hline $\begin{array}{l}\text { Pécs-Danitzpuszta, } \\
\text { Magyarország }\end{array}$ & $\begin{array}{l}\text { felső- } \\
\text { miocén }\end{array}$ & MN9? & homok & $\begin{array}{l}\text { mandibula, } \\
\text { maxilla, femur, } \\
\text { ilium, vertebra }\end{array}$ & $\begin{array}{l}\text { SZENTESi } e t \text { al. } \\
\text { 2020, és jelen } \\
\text { munkában }\end{array}$ \\
\hline ?, Moldávia & miocén & $?$ & ? & ? & TATARINOV 1964 \\
\hline Kuchurgan, Ukrajna & $\begin{array}{l}\text { felső- } \\
\text { pliocén }\end{array}$ & MN14 & ? & $?$ & $\begin{array}{l}\text { ČHKHIKVADZE } \\
1981,1982\end{array}$ \\
\hline $\begin{array}{l}\text { Willershausen, } \\
\text { Németország }\end{array}$ & $\begin{array}{l}\text { felső- } \\
\text { pliocén }\end{array}$ & MN14/15 & ? & ? & $\begin{array}{l}\text { WESTPHAL } 1967, \\
\text { BÖHME } \text { et al. } 2012\end{array}$ \\
\hline
\end{tabular}




\section{VIZSGÁLT ANYAG ÉS MUNKAMÓDSZEREK}

Földtani háttér - A pécs-danitzpusztai homokbánya gödre Dél-Magyarországon, a Mecsek-hegység délkeleti peremén, Pécs városának keleti határánál terül el (SzENTESI et al. 2020: Fig. 1b). Az itt feltárt üledékek a késő miocén során, kb. 11,6-10 millió évvel ezelőtt rakódtak le. Ezek kisebb részben egy idősebb fehér vagy világos színủ mészmárgából és egy fiatalabb, sárga színủ durvahomokból állnak. Az üledékek a Mecsek-hegység szárazon lévő, szigetként kiemelkedő részéről lepusztulás útján szállítódtak az egykori tóba, ezért bennük keverten találhatjuk a Pannon-tó és a régebben létezett szubtrópusi tengerek és szárazföldek ősmaradványait. A rétegsor az üledékképződés közben és után kibillent a Mecsek emelkedése miatt, ezért egy része meredekre állítódott (KONRÁD \& SEBE 2010), így ma a fiatalabb homok nem az idősebb mészmárga tetején, hanem attól délre helyezkedik el. A bányaművelés ezt a fiatalabb, vasásványok által barnássárgára festett durvaszemü homokot érinti (Szentesi et al. 2020: Fig. 1d), melyből számos ösgerinces maradvány került elő (KAZÁR et al. 2007, KonRÁD et al. 2010), többek közt az óriásszalamandra leletek is (SzENTESI et al. 2020).

$\mathrm{Az}$ óriásszalamandra leletek korát megbecsülni nem volt egyszerü feladat. Habár a kövületeket a késő-miocén (alsó-pannóniai/alsó tortoni) homokból került elő, mégsem lehet azt állítani, hogy ez lenne a maradványok kora. Ez a kérdés az Andrias ökológiai igényeinek figyelembe vételével lett megvitatva (SZENTESI et al. 2020). A mai Criptobranchydaek kizárólag nedves területeken fordulnak elő, ahol az éves csapadékmennyiség meghaladja vagy túllépi a $\sim 900 \mathrm{~mm}$-t (BöHME et al. 2012) és az élőhelyként szolgáló patak vagy folyó soha nem fagy be (pl. Browne et al. 2013). A korai késő-miocén idején a lelöhelyről előkerült fosszilis flóra elemzése alapján az éves csapadékmennyiség az egykori területen meghaladta az $1000 \mathrm{~mm}$-t, és a termofil növényzet azt jelzi, hogy a hőmérséklet ekkor nem süllyedt soha a fagypont alá (HABLY \& SEBE 2016), így nagy valószínűséggel az innen előkerült óriásszalamandrák ekkor élhettek itt.

Vizsgált anyag - két töredékes óriásszalamandra caudális vertebra (VER 2015.5-6.), melyeket Bécsi László gyüjtött a Pécs-Danitzpuszta területén található homokbányából.

Dokumentálás - Az ábrákhoz felhasznált fotók Canon EOS 700D fényképezőgéppel, és Canon Macro Lens EF 100 mm, 1:2.8 USM makro objektív segítségével készültek sorozatfotóként. A sorozatfotók összedolgozása Combine ZP, míg utómunkálatai Corel Photo Paint és Draw programok segítségével történt. 


\title{
EREDMÉNYEK
}

\author{
Ordo Caudata Scopoli, 1777 \\ Subordo Cryptobranchoidea Dunn, 1922 \\ Cladum Pancryptobrancha Vasilyan et al., 2013 \\ Classis Amphibia Gray, 1825 \\ Subclassis Lissamphibia Haeckel, 1866 \\ Familia Cryptobranchidae Fitzinger, 1826
}

Genus Andrias Tschudi, 1837

Type species: †Salmandra scheuchzeri Holl, 1831

$\dagger$ Andrias scheuchzeri (Holl, 1831)

caudális vertebrae

(VER 2015.5-6.)

(1-9. ábra)
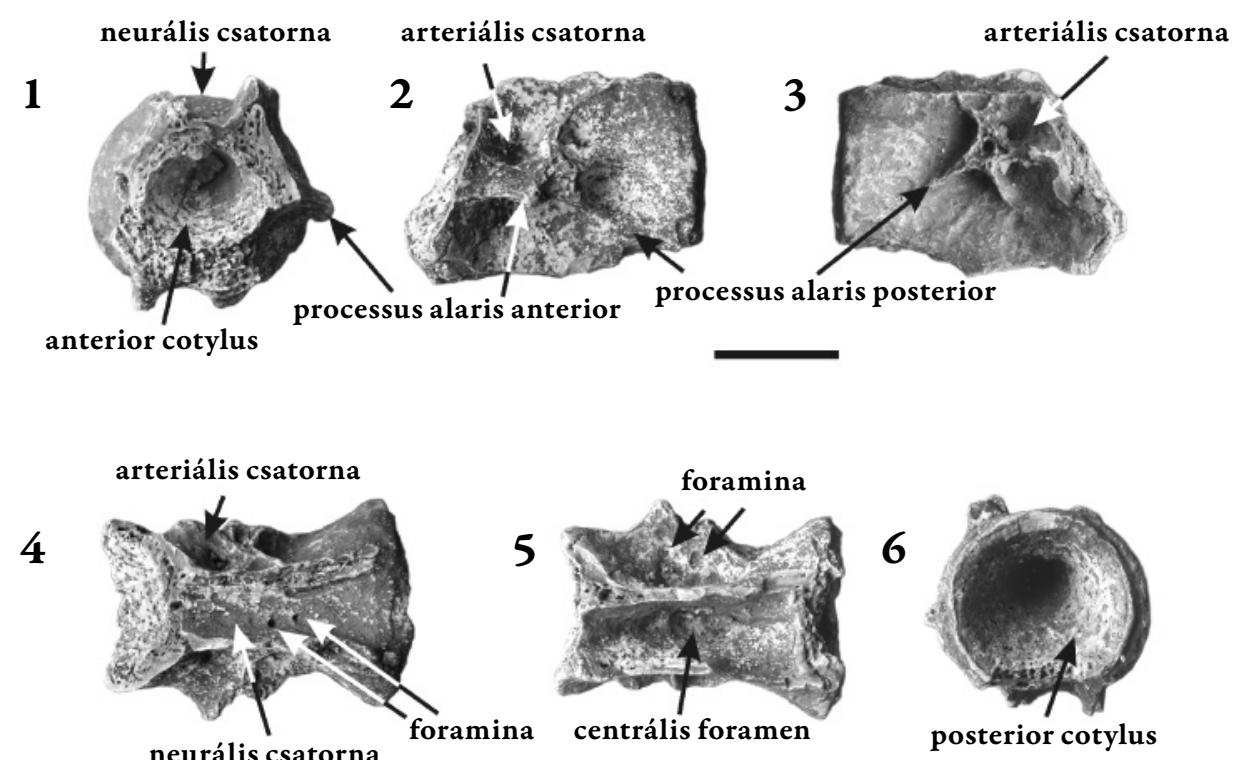

1-6. ábra. Óriásszalamandra ( $†$ Andrias scheuchzeri) caudális vertebra (VER 2015.5.) a pécsdanitzpusztai (Mecsek-hegység, Magyarország) késő-miocén ősgerinces lelőhelyről. $1=$ anterior, $2=$ bal laterális, $3=$ jobb laterális, $4=$ dorzális, $5=$ ventrális és $6=$ posterior nézetben. (méretléc: $1 \mathrm{~cm}$ ) 


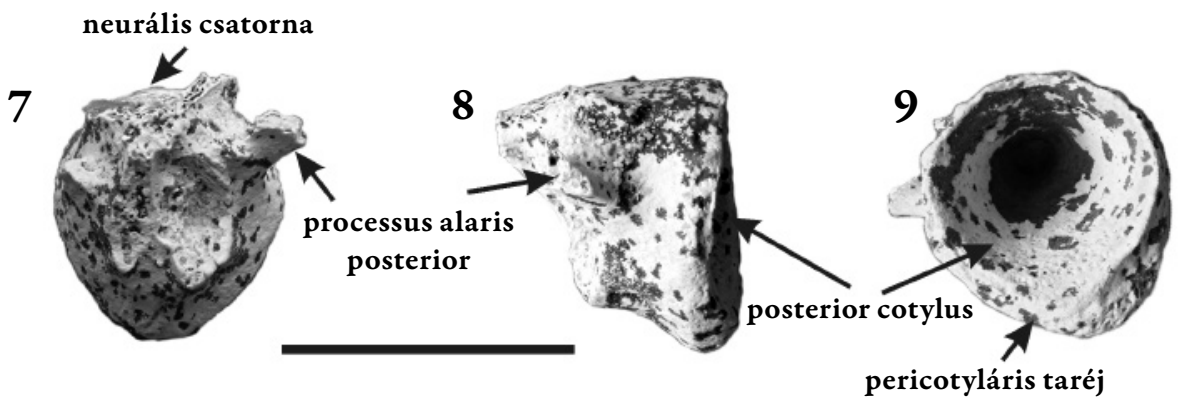

7-9. ábra. Óriásszalamandra ( $†$ Andrias scheuchzeri) caudális vertebra-töredék (VER 2015.6.) a pécs-danitzpusztai (Mecsek-hegység, Magyarország) késő-miocén ősgerinces lelőhelyről. $7=$ anterior, $8=$ jobb laterális és $9=$ posterior nézetben. (méretléc: $1 \mathrm{~cm}$ )

A csigolyák nagyméretủek (a nagyobb $2,4 \mathrm{~cm}$, míg a kisebb töredék $8 \mathrm{~mm}$ hosszú) és robusztus felépítésüek. A kevésbé sérült caudális vertebrán (VER 2015.5., 1-6. ábra) is jobbára csak az amphicoel csigolyatest maradt meg. A neurális és haemalis ív egyaránt törött, akárcsak a laterális nyúlványok. Az anterior és a posterior cotylus egyaránt mély, és tölcsér alakú (1, 6. ábra). Dorzális nézetben a neurális csatorna belsejében több apró foramen figyelhető meg (4. ábra). A posterior nézetben jól fejlett perycotyláris perem figyelhető meg (6 ábra), mely ventrálisan sérült, míg a másik példányon (VER 2015.6.) viszonylag épen maradt meg (9. ábra). Laterális és dorzális nézetben is jól megfigyelhető azonban a jól fejlett, nagyméretű arteriális csatorna (3-4. ábra) a VER 2015.5. példányon, valamint ventrális nézetben a szintén jól fejlett, kör alakú centrális foramen ( 5 . ábra). Szintén ezen a példányon a baloldali processus transversus maradványa vaskos, és erőteljesen terjed ki posterolaterális irányban (2, 4. és 5. ábra). A VER 2015.6. számú példányon a processus alaris posterior nyúlvány maradványa szintén vaskos és erőteljesen mutat anterolaterális irányba (7-9. ábra). Ventrális nézetben, a VER 2015.5. számú példányon, a processus transversus proximális részén néhány apró, kerek foramen figyelhető meg (5. ábra).

A nagyméretű, masszív és amphicoel farokcsigolya jellemző a Pancryptobrancha klád képviselőire (VASILYAN et al. 2013). Az erőteljes processus alarisok és az arteriális csatorna helyzete ezen farokcsigolyáknál hasonló az Ukrainurus hypsognathus-éhoz, azonban különböznek töle a nagyméretű neurális foramen hiányában (4. ábra), és a dorzális nézetben látható centrális foramen mérete lényegesen kisebb, és az alakja is különbözik az itt leírt példányokon (5. ábra), valamint a haemalis ív maradványai is jóval filigránabbak (5. ábra). Figyelembe véve azt is, hogy a danitzpusztai lelőhelyről csak az Andrias scheuchzeri maradványai kerültek elö, a fentebb leírt farokcsigolyák ehhez az óriásszalamandra fajhoz sorolhatóak. 


\section{TÁRGYALÁS}

\section{Tafonómiai észrevételek}

Mindkét példány sérült, erősen töredezett, mely részben a vízben szállítódás, másrészt a területet földtani eseményeihez köthető áthalmozódás következménye lehet (Konrád \& Sebe 2010, Szentesi et al. 2020). Az alapszínük világos, melyet kisebb-nagyobb részben sötétszürke mangános bevonat fed. Ez utóbbi a laza üledékben áramló csapadék és/vagy rétegvizekből válhatott ki a csontok felszínére.

\section{Paleoökológiai és ősföldrajzi következtetések}

A danitzpusztai óriásszalamandrák a kora késő-miocén időszakban élhettek az egykori területen, és maradványaik csak áthalmozódhattak a fiatalabb homokba, ahogy az már fentebb, a földtani résznél már említve lett. Az óriásszalamandrák jelenléte idején uralkodó éghajlat leginkább a lelőhelyről előkerült növénymaradványok alapján rekonstruálható. A babérfélékből és a többi melegkedvelő fajból meleg, fagymentes szubtrópusi éghajlatra lehet következetni, ahol csapadékos és száraz évszakok váltakztak. A növényzet domborzati helyzete alapján is változatos volt. A mai viaszbogyó illetve fenyérmirtusz rokona, a Myrica lignitum nevü cserjefaj volt a leggyakoribb, de a mocsári ciprus egy kihalt faja és a sok egyszikủ is egykori kiterjedt mocsári erdőket jelez, melyek az alacsonyan fekvő területeken tenyészhettek. A magasabb térszíneken a babérfélék, a Kubinyi-tölgy és a melegkedvelő fenyőfélék voltak gyakoriak. Ez a terület növényzete alapján egy refúgium környezet volt a szarmatából visszamaradt növényzet számára, ahol a Mecsek-hegység biztosította a Pannon-tótól magasabb térszínt ehhez (ERDEI et al. 2007, HA BLY \& SEBE 2016). Nincsenek pontos üledékföldtani mutatók az egykori hegyvidék magasságáról, de a durvaklasztos üledékek, a nyíltvízi mészmárga-lerakódás, valamint a korábbi üledékekből származó puhatestủ és gerinces ősmaradványok áthalmozódása és erodálása meredek topográfiát jelez ezen élőhely hátterében (SEBE et al. 2015).

A ma élő óriásszalamandrák tisztavizű, gyorsfolyású patakokban és folyókban élnek (pl. BöHME et al. 2012, BROWNE et al. 2012, 2013), nehezen elképzelhető, hogy a lelőhelyről előkerült óriásszalamandrák a mocsárban, vagy a sós Pannon-tóban (pl. MAgYar et al. 1999) éltek volna. A SEBE et al. (2015) által említett durvaklasztos üledékek kombinálva egy meredek térszínnel azt sugallja, hogy ezt az üledéket gyorsfolyású, nagy energiával áramló vizek rakhatták le a magasabb térszínt erodálva. Ez folyó vagy patak volt-e, azt nem tudni, de az nagyon valószínü, hogy hasonló viszonyokat biztosíthatott az 
óriásszalamandráknak a mai élőhelyeiken tapasztalhatóhoz, és a maradványaikat ez az áramló víz szállította a tóba, vagy a mocsárba. Itt fosszilizálódtak, majd áthalmozódtak, ahogyan az már fentebb említve volt. Az európai miocén korú lelőhelyek földtani adatait megvizsgálva szembetűnő, hogy az Andrias leletek hegylábi, hegységelőtéri medencék tavainak agyag- és homok üledékeiből (édes- és brakkvízi molasz) kerültek elő (1. táblázat). BöHME et al. (2012) munkájában azt valószínüsíti, hogy a ma kizárólag gyorsfolyású tiszta vizekben élő óriásszalamandrák (pl. BrownE et al.) ezen időszakban ezekben a tavakban éltek, és a ma élő fajok később foglalták el jelenlegi élőhelyeiket. Ez az állítás földtani szempontból mindenképpen kérdéses, hiszen a pécs-danitzpusztai lelőhelyhez hasonlóan ezekbe az egykori tavakba is a hegységekből lezúduló, gyorsan áramló vizű folyók és/vagy patakok szállíthatták ezen állatok maradványait a megtalálási helyükre. Ezt támasztja alá az is, hogy a leletek nagytöbbsége kizárólag izolált csontokból áll. Finomabb üledékekből előkerült néhány a részleges csontváz, de ezek is erősen hiányosak.

\section{ÖSSZEGEZÉS}

A fentebb leírt, felépítésük alapján az Andrias scheuchzeri óriásszalamandra fajhoz sorolható farokcsigolyák eddig még nem voltak ismertek a pécsdanitzpusztai miocén korú lelőhelyről. A lelőhelyen más óriásszalamandra faj jelenlétére utaló maradvány nem került elö, sőt a hasonló korú európai lelőhelyekről sem, így ez is azt támasztja alá, hogy ezen fosszíliák a fent említett fajhoz sorolhatóak.

A lelőhelyről ismertté vált óriásszalamandrák a magasabb topográfiáról lezúduló, gyorsfolyású vizekben élhettek, onnan kerülhettek maradványaik az eredeti ülepedési környezetükbe, ahonnan később áthalmozódhattak.

Nagy valószínűséggel az Európa miocénjéből előkerült óriásszalamandrák is gyorsfolyású, tiszta vizű folyókban és/vagy patakokban élhettek, és ezen folyóvizek szállíthatták maradványaikat az egykori tavakba.

Köszönetnyilvánitás - A szerző hálával tartozik Bécsi László magángyűjtőnek, aki a Magyar Természettudományi Múzeumnak ajándékozta az itt leírt óriásszalamandra leleteket, és Szabó Mártonnak, aki felhívta a figyelmemet a leletekre. Köszönöm Venczel Mártonnak (Nagyvárad, Kőrösvidék Múzeum) a munka alapos átnézését, és szakszerủ bírálatát. 


\section{HIVATKOZÁSOK}

Bӧнме M. 2003: Miocene climatic optimum: evidence from the lower vertebrates of Central Europe. - Palaeogeography, Palaeoclimatology, Palaeoecology 195: 389-401.

Bӧнме M. 2008: Ectotermic vertebrates (Teleostei, Allocaudata, Urodela, Anura, Testudines, Choristodera, Crocodylia, Squamata) from the Upper Oligocene of Oberleitersbach (Northern Bavaria, Germany). - Courier Forschungsinstitut Senckenberg 260: 161-183.

Böнme M. \& Ilg A. 2003: fosFARbase. www.wahre-staerke.com2003 (accessed April 2021)

Böhme M., VAsilyan D. \& Winklhofer M. 2012: Habitat tracking, range dynamics and palaeoclimatic significance of Eurasian giant salamanders (Cryptobranchidae) indications for elevated Central Asian humidity during Cenozoic global warm periods. Palaeogeography, Palaeoclimatology, Palaeoecology 342-343: 64-72.

Böttcher R. 1987: Neue Funde von Andrias scheuchzeri (Cryptobranchidae, Amphibia) aus der süddeutschen Molasse (Miozän). - Stuttgarter Beiträge zur Naturkunde Ser. B. 131: 1-38.

Browne R. K., Li H., Wang Z., Hime P., McMillan A., Wu M., Diaz R., Hongxing Z., MCGinnity D. \& BRiggler J. T. 2012: The giant salamanders (Cryptobranchidae): Part A. palaeontology, phylogeny, genetics, and morphology. - Amphibian and Reptile Conservation 5(4): 17-29.

Browne R. K., Li H., Wang Z., Okada S., Hime P., McMillan A., Wu M., Diaz R., McGinnity D. \& Briggler J. T. 2013: The giant salamanders (Cryptobranchidae): Part B. Biogeography, ecology and reproduction. - Amphibian and Reptile Conservation 5(4): 30-50.

ČER ̌̌ANSKỲ A. 2007: Plazy miocénnych lokalit Českej republiky a Slovenska. - Doktori dolgozat, Comenius Egyetem, Pozsony, Szlovákia, 68 pp.

Chernov S. A. 1959: Reptiles 18. - Academy of Sciences Tajik SSR, Stalinbad, 202 pp.

ČHIKVADZE V. M. 1981: Obzor svedeniï ob iskopaemykh ostatkakh amfibiï i reptiliï Severnogo Prichernomorya. - Voprosy gerpetologii, p. 5.

ČHIKVADZE V. M. 1982: On the findings of fossill Cryptobranchidae in the USSR and Mongolia. Vertebrata Hungarica 21: 63-67.

Erdei B., Hably L., Kázmér M., Utescher T. \& Bruch A. A. 2007: Neogene flora and vegetation development of the Pannonian domain in relation to palaeoclimate and palaeogeography. - Palaeogeography, Palaeoclimatology, Palaeoecology 253: 115-140.

GaO K. Q. \& ShUbiN N. H. 2003: Earliest known crown-group salamanders. - Nature 422: 424-428.

Hably L. \& Sebe K. 2016: A late Miocene thermophilous flora from Pécs-Danitzpuszta, Mecsek Mts., Hungary. - Neues Jahrbuch für Geologie und Paläontologie, 279(3): 261-271.

Kazár E., Kordos L. \& Szónoky M. 2007: Danitz-puszta. In: Pálfy J. \& Pazonyi P. (szerk.) Öslénytani kirándulások Magyarországon és Erdélyben. - Hantken Kiadó, Budapest, pp. 131-132.

Kirscher U., Prieto J., Bachtadze V., Aziz H. A., Dopple G., Hagmeier M. \& Böhme M. 2016: A biochronologic tie-point for the Tortonian stage in European terrestrial settings: Magnetostratigraphy of the topmost Upper Freshwater Molasse sediments of the North Alpine Foreland Basin in Bavaria (Germany). - Newsletters on stratigraphy 49(3): 445-467. 
Kleb B. 1973: Geologie des Pannons im Mecsek. - Magyar Állami Földtani Intézet évkönyve 53(3): 750-943.

Konrád Gy., Kordos L. \& Sebe K. 2010: Danitz-pusztai homokbánya. Pécs, Mecsek. Őslényvadászat a Pannon-tó peremén. In: Haas J. (szerk.) A múlt ösvényein. - Magyarhoni Földtani Társulat, Budapest, pp. 160-164.

Konrád Gy. \& SEBE K. 2010: Fiatal tektonikai jelenségek új észlelései a Nyugati-Mecsekben és környezetében. - Földtani Közlöny 142(2): 445-468.

Kvačen Z., Böhme M., Dvoŕák Z., Konzalová M., Mach K., Prokop J. \& RajChl M. 2004: Early Miocene freshwater and swamp ecosystems of the Most Basin (northern Bohemia) with particular reference to the Bílina Mine section. - Journal of the Czech Geological Society 49(1-2): 1-40.

Magyar I., Geary D. H. \& Müller P. 1999: Palaeogeographic evolution of the Late Miocene Lake Pannon in Central Europe. - Palaeogeography, Palaeoclimatology, Palaeoecology 147(3): 151-167.

Meszoely C. A. M. 1966: North American cryptobranchid salamanders. - American Midland Naturalist 75: 495-515.

Miklas P. M. 2002: Die Amphibienfauna (Amphibia: Caudata, Anura) der Obermiozänen Fundstelle Götzendorf an der Leitha (südliches Wiener Becken, Niederösterreich. Annalen des Naturhistorischen Museums in Wien 103: 161-211.

Mörs T., von Der Hocht F. \& Wutzler B. 2000: Die erste Wirbeltierfauna aus der Miozänen Braunkohle der Niederrheinischen Bucht (Ville-Schichten, Tagebau, Hambach). Paläontologische Zeitschrift 74(1/2): 145-170.

NAYLOR B. G. 1981: Cryptobranchid Salamanders from the Paleocene and Miocene of Saskatchewan. - Copeia 1981(1): 78-86.

SACH V. J. \& Heinzmann P. J. 2001: Stratigraphie und Säugetierfaunen der Brackwassermolasse in derUmgebung von Ulm (Südwestdeutschland). - Stuttgarter Beiträge zur Naturkunde Serie B, Geologie und Paläontologie 310: 1-95.

Sebe K., Csillag G., Dulai A., Gasparik M., Magyar I., Selmeczi I., Szabó M., Sztanó O. \& Szuromi-Korecz A. 2015: Neogene stratigraphy in the Mecsek region. In: Bartha I. R., Kriván Á., Magyar I. \& Sebe K. (eds.) Neogene of the Paratethyan Region, $6^{\text {th }}$ Workshop on the Neogene of Central and South-Eastern Europe. An RCMNS Interim Colloquium. Programme, Abstracts, Field Trip Guidebook. 2015.05.31-06.03, Orfü. Budapest, Magyar Állami Földtani Intézet, pp. 102-124

SEEHUBER U.2008: Litho-und biostratigraphische Untersuchungen in der Oberen Süßwassermolasse in deer Umgebung vom Kircheim in Schwaben. - Inaugural-Dissertation zur Erlangung des Doktorgrades der Fakultät für Geowissenschaften der Ludwig- Maximilians-Universität München, $359 \mathrm{pp}$.

Szentesi Z., Sebe K. \& Szabó M. 2020: Giant salamander from the Miocene of the Mecsek Mountains (Pécs-Danitzpuszta, southwestern Hungary). - Paläontologische Zeitschrift 94:353-366.

Tatarinov L. P. 1964: Podklass Lepospondyli. Lepospondilnye. - Osnovy paleontologii, zemnovodnye, presmykayushchiesya, ptitsy, Nauka, Moszkva, pp. 144-170. 
Tempfer P. M. 2004: Andrias scheuchzeri (Caudata: Cryptobranchidae) aus der Obermiozänen (MN7/8) Fundstelle Mataschen/Steiermark. - Joannea Geologie und Palaontologie 5: 257-268.

Thenius E. 1954: Über das Vorkommen von Riesensalamandern (Cryptobranchidae, Amphibia) im Unterpliozän (Pannon) des Wiener Beckens. - Paläontologische Zeitschrift 28: 172-177.

Vasilyan D., Böhme M., Chkhikvadze V. M., Semenov Y. A. \& Joyce W. G. 2013: A new giant salamander (Urodela, Pancryptobrancha) from the Miocene of Eastern Europe (Grytsiv, Ukraine). - Journal of Vertebrate Paleontology 33(2): 301-318.

Westphal F. 1958: Die Tertiären und Recenten Riesensalamander (Genus Andrias, Urodela, Amphibia). - Palaeontographica, Abteilung A. 110: 20-92.

Westphal F. 1967: Erster Nachwels des Riesensalamander (Andrias, Urodela, Amphibia) in europäischen Jungpliozän. - Neues Jahrbuch für Geologie und Paläontologie Monatshefte: 67-73.

Westphal F. 1970: Neue Riesensalamanderfunde (Andrias, Amphibia) aus der oberen Süsswassermolasse von Wartenberg in Bayern. - Mitteilungen der Bayerischen Staatssammlung für Paläontologie und Historische Geologie 10: 253-260.

\title{
Scattered fossils in the collection of Hungarian Natural History Museum: vertebrae of giant salamande, †Andrias scheuchzeri (Holl, 1831): caudal vertebrae from the Late pannonian Miocene paleovertebrate locality of Pécs-Danitzpuszta (Hungary) (Caudata: Amphibia: Cryptobranchidae)
}

\author{
ZOLTÁN SZENTESI \\ Hungarian Natural History Museum, Department of Paleontology and Geology, \\ H-1088 Budapest, Pf. 137., Hungary \\ E-mail:szentesi.zoltan@nhmus.hu
}

\begin{abstract}
Fossils of giant salamander ( $\nmid$ Andrias scheuchzeri) are only known from paleovertebrate locality of Pécs-Danitz Puszta (Mecsek Hills) of Hungary which consists of cranial and postcranial bone elements. Despite this, caudal vertebrae have not been described yet from this site. This work seeks to make for this with some paleoecological and paleogeographical notes. Nine figures, one plate.
\end{abstract}

Keywords - Andrias, Cryptobranchidae, Danitzpuszta, Mecsek, Miocene, vertebrae 


\section{TABLE AND FIGURE LEGENDS}

Table 1. Paleovertebrate localities of giant salamander ( $\nmid$ Andrias, Cryptobranchidae) in Europe. Countries for localities (in the first column): Ausztia = Austria; Csehország = Czechia; Magyarország = Hungary; Moldávia = Moldova; Németország = Germany; Ukrajna = Ukraine. Alluvial types (in the third column): agyag = clay; agyagmárga = clay marl; brakkvízi molasz = brackish water molasse; congériás homok = congerian sand; fluviális üledékek = fluvial deposits; édesvízi molasz $=$ freshwater molasse $;$ homok $=$ sand; mészhomok $=$ calcareous sand; homokos finom kavics = sandy fine gravel; karsztos üregkitöltés = karstic sinkhole deposits; meszes márga $=$ calcareous marl molasz $=$ molasse .

Figs. 1-6. Caudal vertebra (VER 2015.5.) of giant salamander ( $\dagger$ Andrias scheuchzeri) from the Late Miocene paleovertebrate locality of Pécs-Danitzpuszta (Mecsek Hills, Hungary). $1=$ anterior, $2=$ left lateral, $3=$ right lateral, $4=$ dorsal, $5=$ ventral and $6=$ posterior views. (scale bar: $1 \mathrm{~cm}$ )

Figs. 7-9. Caudal vertebral fragment (VER 2015.6.) of giant salamander ( $\dagger$ Andrias scheuchzeri) from the Late Miocene paleovertebrate locality of Pécs-Danitzpuszta (Mecsek Hills, Hungary). $7=$ anterior, $8=$ right lateral and $9=$ posterior views. $($ scale bar: $1 \mathrm{~cm})$ 